\title{
A Survey of Trends and Figures in Afro-American Fiction ${ }^{1}$
}

\section{Per Seyersted}

University of Oslo

In the words of Saunders Redding, the black American, 'and especially, later, the Negro writer, has always known who he is.' He has not had to look for it, because-with a tenseness sometimes bordering on the psychotic-he has known that his 'identity was locked into the white man's fantasy construct of the slave, and [that] Emancipation did not free him.'2

But this did not mean that the black poet or novelist has any advantages over the more typical American writer who traditionally has to try to define who he is. As Langston Hughes has said, 'The Negro writer in America has all the problems any other writer has, plus a few more..' ${ }^{3}$ It is doubtful that anyone has described these additional problems better than Chester Himes:

From the start the American Negro writer is beset by conflicts. He is in conflict with himself, with his environment, with his public. The personal conflict will be the hardest. He must decide at the outset the extent of his honesty. He will find it no easy thing to reveal the truth of his experience or even to discover it. He will derive no pleasure from the recounting of his hurts. He will encounter more agony by his explorations into his own personality than most non-Negroes realize. For him to delineate the degrading effects of oppression will be like inflicting a wound upon himself. He will have begun an intellectual crusade that will take him through the horrors of the damned. And this must be his reward for his integrity: he will be reviled by the Negroes and whites alike. Most of all, he will find no valid interpretation of his experiences in terms of human values until the truth be known.

If he does not discover this truth, his life will be forever veiled in mystery, not only to whites but to himself; and he will be heir to all the weird interpretations of his personality.

What Himes refers to here is the stereotypes used by white authors when they tried to depict black Americans: the contented slave, the wretched freedman, the comic minstrel, the submissive Christian, and the tragic octoroon, to name some of the stock 
characters found by Sterling Brown in authors like Harriet Beecher Stowe, Thomas Nelson Page, and George Washington Cable. ${ }^{5}$

What we miss in this list of black characters is of course the angry slave who wants to revolt against his Uncle Tom-bondage, and the resentful freedman who hates being jim-crowed. To be sure, white authors could not entirely keep their eyes shut to what they must have seen or sensed. In 'Benito Cereno' (1856), Melville described revolting slaves, and in 1879 Albion W. Tourgée wrote about a Negro who 'openly and boldly declared the monstrous doctrine that the colored people ought to defend themselves and each other' against the abuses they were subjected to by the whites. ${ }^{6}$ And a writer like Mark Twain used The Tragedy of Pudd'nhead Wilson (1894) to characterize slavery as worse than death (Ch. 16) and to show that an Afro-American can remember 'insults and injuries' (Ch. 8). On the whole, however, white authors left out such threatening characteristics in their treatment of the blacks.

When black writers appeared on the American scene some 200 years ago, they, too, adhered to the stereotypes created by the white authors. Indeed, almost up to Richard Wright, most AfroAmerican writers portrayed their fellow blacks largely the way the whites wanted to see them. Seymour L. Gross gives a telling illustration of this: When a number of blacks in 1902 brought out a book called Twentieth Century Negro Literature and devoted a section of it to a discussion of 'The Negro as Writer,' none of them felt the need, as Gross puts it, 'to correct the false image of the race promulgated by white literature." As an Afro-American elite, the black writers wanted to be accepted by the white middle class. Therefore they refused to look for or reveal the truth of their experience and refrained from challenging the idea that the whites were a superior race. Furthermore, they disdained the wealth of black literary material they had inherited (e.g. in their folktales), just as they showed contempt for the underprivileged black masses.

There were of course some Afro-American writers who refused to follow this general trend and who insisted instead on an openeyed exploration of the true black experience. W.E.B. DuBois and Sutton Griggs are just two examples. In 1903, DuBois published The Souls of Black Folk in which he gave forceful expression to the frustrations of Afro-American life while showing pride in the black heritage. At the same time he also gave one of the first 
graphic illustrations of some of the difficulties encountered by the blacks when they wanted to define themselves:

The Negro is a sort of seventh son, born with a veil, and gifted with secondsight in this American world, - a world which yields him no true self-consciousness, but only lets him see himself through the revelation of the other world. It is a peculiar sensation, this double-consciousness, this sense of always looking at one's self through the eyes of others, of measuring one's soul by the tape of a world that looks on in amused contempt and pity. One ever feels his twoness, an American, a Negro; two souls, two thoughts, two unreconciled strivings; two warring ideals in one dark body, whose dogged strength alone keeps it from being torn asunder. 8

Sutton Griggs, on his part, brought out in 1899 a nationalist work called Imperium in Imperio. Robert A. Bone writes about Griggs' work that it contains 'the most militant note of the period.'9 Other commentators have termed Imperium in Imperio the first black revolutionary novel. This title seems to belong to Martin R. Delany's Blake or the Huts $₫$ America, however, a work which was serialized in 1859-62 and long believed lost, but which has now been recovered nearly in full and in 1970 brought out in book form. ${ }^{10}$ After the publication of 76 (rather than the previously available 26) chapters out of Blake's original 80, and the appearance in 1972 of Dorothy Sterling's The Making $₫$ an Afro-American: Martin Robinson Delany, 1812-1885, we can now see that Delany was a remarkable writer and that Blake might be said to be the first important novel written by an Afro-American. Surprisingly, the book has as yet been little discussed by other commentators.

Blake, the main character, is a black Southern who preaches revolt against slavery and who goes to Cuba in the $1850^{\prime}$ s to lead a black revolutionary force which aims at overthrowing the government there. Since it is the last six chapters of the book that are missing, we unfortunately do not know how it ends, but we have enough to see Blake's attitudes. 'I now declare war against our oppressors,' he says, and this aim is to 'free [his] race' and to 'bring deliverance to the captive.' To achieve this, every black 'is to seize a white and slaughter 'im.' Blake is proud of his race and his heritage, and he foresees a great future for Africa and for Africans everywhere. The novel is rather melodramatic, but there is no question about the author's sincerity and depth of feeling, and the book is a landmark in black writing. ${ }^{11}$

As we know, the Afro-Americans were more deprived of their roots than any other group of Americans. Through their constant 
dislocations they lost both the sense of home and the sense of place. Families and tribes were separated, and English was made their only language. They were taught to be ashamed of their origins. Thus it was not surprising that, up to around 1920, black writers with the exception of Delany, Griggs, DuBois and a few others closed their eyes to the reality of their hurts and emphasized instead subjects and attitudes that were acceptable to the white middle class.

In Afro-American literature of the 1920's, the blacks were still seen through stereotypes. This was the period when the whites in general discovered the Afro-American and many white authors wrote about him. The stereotype they now concentrated on was the Exotic Primitive --jazz and African masks were then just being discovered. O'Neill, for example, wrote about a black man returning to savagery, and Sherwood Anderson celebrated black sensuality as opposed to the sterility of whites. In black writing of this period we speak of the 'Negro Renaissance' - black authors showed great activity and a new confidence in the 1920's. While some continued the previous deference to the whites, others demonstrated racial pride.

The major work of the Negro Renaissance is Jean Toomer's Cane (1923) ${ }^{12}$ This is the first fictional work by an Afro-American that is artistically satisfying. Prose sections and pieces of poetry are fused into a unified work of art in which the author on the one hand suggests the sufferings of the slaves and freedmen, and on the other, praises the positive aspects of the black heritage. Thus in Part I, set in the South, Toomer describes a lynching and the unhappiness caused by miscegenation, while also celebrating the Afro-American's closeness to the soil and his healthy sexuality the cane stands for the regenerative principle.

In Part II, which is set in Washington, Toomer juxtaposes sterile, conformist whites with blacks who have retained something natural through their Afro-Southern heritage.

The last section of Cane is again set in the South. Here Toomer introduces blacks representing a specter of attitudes toward their past and present, from the old man who curses the whites for misusing the Bible to justify slavery, to the young girl who draws strength from it for the future. The author's mouthpiece stands inbetween these two, realizing both 'the pain and beauty of the South.' Toomer is fully aware of how the whites still emasculate the blacks, but his emphasis is on an acceptance and a utilization 
of the Afro-American heritage, and he seems to say that the black man's closeness to nature in a way makes him a fuller person than the white man. ${ }^{13}$

During the 1930's, Afro-American literature was inevitably influenced by the marxist ideology that prevailed during most of this decade. The black writer could now identify with suffering Americans in general, while his own protest had become acceptable and perhaps understandable to others. Now, finally, could he begin to suggest the pain and bitterness he felt.

A good many black authors were active in the angry decade. One of them was Arna Bontemps, who in 1936 published Black Thunder. Some black critics see this as the best novel we have on Afro-American revolt: Based on official Virginia records from 1800 , Black Thunder deals with the abortive rebellion led by Gabriel Prosser.

The Afro-American protest of this time is found above all in the work of Richard Wright. In 1938 he collected some stories he had written for the Communist press in Uncle Tom's Children, prefacing them with the declaration that 'Uncle Tom is dead,' and in 1940 he followed it with what is in many respects the most important work in black American fiction, the novel Native Son.

In this well-known work, Bigger Thomas, a young Afro-American from the black slum of Chicago, gets a job as a chauffeur with a white family. One night he has to help the drunk daughter to her room, and when her blind mother comes into the room, he is so scared of what she might think if the daughter should speak and betray his presence that he silences the girl with a pillow, so long that she dies. But Bigger understands that it was not entirely an accident. He realizes that for years he has hated the whites who suppress the blacks and regard them as invisible. As the critics have pointed out, in killing Mary Dalton he has symbolically killed the forces which oppressed him and made him anonymous. When Bigger says: 'What I killed for, I am!' it means that he exists because he acted. His action gave him the identity which he felt the whites had denied him. ${ }^{14}$

Here, at long last, was a book in which an Afro-American managed to face the truth about his situation as a black man. While serving as an eye-opener for the blacks, it was shocking to the whites: That Bigger felt it necessary to murder a white person in order to achieve his selfhood was hard to take even for white liberals. Yet this complete protest against the black man's lot had 
a tremendous impact, which Irving Howe has summed up in this way:

The day Native Son appeared, American culture was changed forever. No matter how much qualifying the book might later need, it made impossible a repetition of the old lies. ... A blow at the white man, the novel forced him to recognize himself as an oppressor. A blow at the black man, the novel forced him to recognize the cost of his submission. ... Speaking from the black wrath of retribution, Wright ... told us the one thing even the most liberal whites preferred not to hear: that Negroes were far from patient or forgiving, that they were scarred by fear, that they hated every minute of their suppression even when seeming most acquiescent, and that often enough they hated us, the decent and cultivated white men who from complicity or neglect shared in the responsibility for their plight. ${ }^{15}$

In spite of the consciousness-raising effect of this book, there were, for some 25 years, few Afro-Americans who followed Wright with his militant kind of protest in Native Son. Until the emergence of the Black Power movement in the middle 1960's, black writers, though unquestionably influenced by their great literary mentor, were also in opposition to him. Both Ellison and Baldwin were critical of the social protest in Native Son, which they felt spoiled it artistically. Ellison complained about the sociological approach which denied those racial qualities which are of value beyond any question of suppression. Nor could Baldwin go along with Wright's assertion that only through struggle could the blacks achieve their humanity. In his famous essay from 1949, 'Everybody's Protest Novel,' he wrote that we need not battle for our humanity, but that we must do what is much more difficult, that is, accept it. In Baldwin's view, Wright makes Bigger Thomas into a sub-human when he fights for his humanity, when the author deprives him of such normal human qualities as love and fellowship with those around him. 'The failure of the protest novel,' he writes, 'lies in its rejection of life, the human being, the denial of his beauty, dread, power, ... in its insistence that it is his categorization alone which is real and which cannot be transcended.'16

In 1947, Wright expatriated to France, and in a sense he then also left his race behind. He seems to have suffered from a deep self-hatred from which he tried to escape. He rejected the values of his fellow Southern blacks, and apparently he even rejected his blackness declaring that he had no race except that which was forced upon him, that he had no traditions, that he was free.

Ellison and Baldwin, meanwhile, did not agree with Wright on 
this point: they insisted on their cultural and historical ties with their fellow American blacks. Ellison maintained that Wright's undervaluation of the importance of the black heritage gave a meager kind of freedom, with no roots to strengthen one's identity. He denies that blacks have a monopoly on tragedy and that suffering is their only real experience. While he condemns the whites' oppression of the blacks, he at the same time asserts that the particular experience of the Afro-Americans has instilled in them certain admirable qualities which are lacking in most whites, such as patience, humor, and a 'rugged sense of life.' ${ }^{17}$. We see something of this rugged sense of life in Ellison's Invisible Man. This book is, together with Wright's Native Son and Baldwin's Go Tell It on the Mountain, the most important black novel in America. Some years ago it was judged by a poll of 200 critics to be the 'most distinguished single work' of American fiction published since World War II. ${ }^{18}$

The protagonist of this well-known work is not only invisible, he is also unnamed, and he does not know who and what he is. We see how he as a schoolboy in the South is exposed to degradations and how he gets a first let-down from the Afro-American president of his black college. We follow him to New York where he believes he has found certain values in 'The Brotherhood' which he joins obviously the Communist Party - only to find that they have taken advantage of him.

The invisible man had denied his black heritage, but now he more and more accepts it. One symbol for this is that he begins again to eat typical Afro-American food. He takes the side of his fellow blacks in a race riot in Harlem. During it, he falls down into the basement of a building, and here he spends his time, trying to think through the problem of blackness. He realizes that while his color makes him physically prominent, it at the same time makes him socially invisible in the sense that he is not recognized by the whites as a human being.

At the end of the book, Ellison's protagonist says that the time has come for him to go out of his hibernation, but it is not clear what he is going to do in society. The ending is open to many interpretations. To me it seems that Ellison is saying that just because the Afro-Americans know so well what it means to be underprivileged, it is their mission to uphold the principles on which America was founded. This reading is supported by what Ellison has written in a recent article entitled 'What America Would Be Like Without Blacks' : 
Materially, psychologically and culturally, part of the nation's heritage is Negro American, and whatever it becomes will be shaped in part by the Negro's presence. Which is fortunate, for today it is the black American who puts pressure upon the nation to live up to its ideals. It is he who gives creative tension to our struggle for justice and for the elimination of those factors, social and psychological, which make for slums and shaky suburban communities. It is he who insists that we purify the American language by demanding that there be a closer correlation between the meaning of words and reality, between ideal and conduct, our assertions and our actions. ${ }^{19}$

Ellison wants change to be brought about through peaceful means. In an interview in 1969 he repeats what he has said before, that he questions militant action and is against separatism. Here he also tells us a little about his long-awaited second novel, which he began in 1956. We are still waiting for what we hope will be another important book. ${ }^{20}$

As we know, Baldwin has been much more productive. But he had to go abroad to get started. 'My journey, or my flight, had not been to Paris, but simply away from America,' as he writes in the opening section of his recent book, No Name in the Street (1972). He tried to leave his Americanness and his blackness behind, but Paris made him see that he was as American as anybody, and the records of Bessie Smith taught him to feel and accept that he was a black man. He realized that you have to know your roots to know who you are, and that self-knowledge is a prerequisite for a selfacceptance, without which you cannot lead a meaningful life. Baldwin found that much of the black American heritage was adopted from the white civilization, and not surprisingly, in his first novel, Go Tell It on the Mountain, the ex-preacher concentrated on the effects of the Christian religion on the lives of the AfroAmericans.

The aspect of Christianity which Baldwin emphasizes is that 'Jesus saves,' that is, he promises the blacks a rich otherworldy life as a compensation for what they cannot get in this earthly existence. The Church gives the black a safe haven in the sense that it, on the one hand, gives the Afro-Americans an excuse for their selfhatred, and on the other, gives them a feeling that they are a chosen people who shall one day stand forth in glory.

In this magnificent story of the life of three generations of blacks, set in the South and in New York, Baldwin gives us a shattering evocation of the power of the Church ruled by 'Blindness, Lonelines, and Terror,' as he sums it up in The Fire Next Time (1963).

But even as John Grimes in the end is 'saved' and chooses the 
Church, he seems to be somewhat liberated from fear and selfhatred. As I see it, when he prays for strength to stand against everything that wants to cut down his soul, and when he says that he is coming and is on his way, he is not headed for a self-assertion against the whites, but for a general self-exploration. He is ready for knowledge, for love and self-realization, a self-realization which, as we see in a story on the later John Grimes, also includes homosexuality. In the same way, the main point of Baldwin's later novels, it seems to me, is not so much the frequent racial encounters per se, but rather the questions of selfknowledge and self-acceptance they bring to the fore. The Afro-American and the homosexual are both outsiders trying to define their own values. From this point of view, the white homosexual Eric Jones is the main character in the highly interesting Another Country because he, like the black, bisexual Leo Proudhammer in Tell Me How Long the Train's Been Gone, is the one who is able to accept himself and who consequently can love and help others.

With this emphasis on love, Baldwin predictably has had some difficulty in going along with the Black Power movement. True, he introduced a black activist in one of his latest novels, and in 'An Open Letter to my Sister, Miss Angela Davis' he writes that 'we must fight for your life ... and render impassable with our bodies the corridor to the gas chamber. For, if they take you in the morning, they will be coming for us that night.' But this is mostly lip service to the activists. His chief point, as we see again in a recent interview, is love: Once more he evokes the picture of his mother who taught him that 'la chose la plus importante au monde, c'était de nous aimer les uns les autres, et d'aimer autrui. ${ }^{21}$

Another prominent and prolific Afro-American author who kept his protest rather mute was Langston Hughes. In the 1950's he created his best-known character, Simple. This black man from Harlem, Hughes writes, 'tells me his tales, mostly in high humor, but sometimes with a pain in his soul as sharp as the occasional hurt of that bunion on his right foot.' Simple exposes the whites when he tells about present life on the sidewalk: 'The cops don't even say, "Move on," hardly no more. They learned something from them Harlem riots. They used to beat your head right in public, but now they only beat it after they get you down to the stationhouse.' But Hughes also lets Simple show his fine irony in connection with blacks.

Simple himself is a very human person. Some of his problems 
are universal, and he has great appeal also to nonblacks. Meanwhile, we also sense the simmering nationalism of the Negroes. Simple is willing to use a gun and fight the whites, and he predicts that one day he will be on top. ${ }^{22}$

One of the most interesting figures in modern Afro-American fiction is John A. Williams. In 1967 he published what is probably his best book so far, The Man who Cried I Am, a novel which shows his disillusionment with white Americans.

Max Reddick, the main character of the book, is a black journalist who runs the African desk of a national magazine. His job takes him to Africa, his 'homeland,' but he feels rejected there by his own race. ${ }^{23}$ In America, he had held the whites responsible for the death of the black woman he loved, but even so he follows the example of his fellow black writer Harry Ames (modeled on Richard Wright) and marries a white woman. He wants integration to be possible and takes his Dutch wife to the States, but he soon finds out that it does not work, and he becomes increasingly embittered with the ruling race. When Ames is dying he gives Reddick papers showing that there exists a White House plan to exterminate all blacks if they should start a large-scale insurrection, and Max is killed when he tries to warn a Negro leader who is clearly Malcolm X. It has been said that 'Williams believes that a 'contingency plan' of some sort does exist. He carries with him a prepared statement explaining the reasons for his belief. 'The plain, unspoken fact is that the Negro is superfluous in American society as it is now constructed. Society must undergo a restructuring to make a place for him, or it will be called upon to get rid of him.'24

The logical answer to this white oppression of the blacks, Williams seems to say, is more black power. In a recent book, the novel Captain Blackman (1972); he rewrites American military history by reminding us of forgotten black bravery. In an earlier novel, Sons \& Darkness, Sons of Light (1969), Williams had illustrated what the blacks will do if America does not change radically: They will rise. The brutal treatment of Afro-Americans by white policemen triggers a black revolution led by Black Panther-type groups. There is something desperate about the whole thing: The blacks do not succeed in their aim of changing society, and they are not able to cooperate with each other. As it has been said, Williams describes the revolution not so much as a cure as an inevitable result of the sickness of racism. ${ }^{25}$

Another author who has been even more outspoken than Willi- 
ams is Sam Greenlee in his The Spook Who Sat by the Door (1969). It tells the story of Dan Freeman, an intelligent, educated AfroAmerican who is accepted into the CIA as a showpiece of integration. Secretly he trains himself in insurrectionary techniques, and when he goes to work for a civil rights organization in Bigger Thomas' Southside Chicago, he trains the Cobras, the gang he himself once belonged to, into a secret and highly efficient guerilla unit. Some of the men trained by him go to other cities to organize similar groups there. When troops are called in to quell a Chicago summer riot, the Cobras start the insurrection. Freeman is killed, but others are ready to take over, and as the book ends, several cities are in turmoil.

In a way, the book reads like a thriller. We see Freeman's cool efficiency as he absorbs the latest guerilla techniques under the cover of an Uncle Tom: He is one kind of a spook (spade, or black man) who becomes an other kind of a spook (aCIAagent) by acting as the ofays (whites) want him to be, i.e. by showing them that he does not want to integrate with them in private life. The invisibility which Negroes otherwise complain about is his safeguard against being noticed by 'whitey.' At the same time, he wants total freedom, freedom to stand up like a man, unoppressed. While posing as the perfectly 'superficial, materialistic, white-type, middle-class' Afro-American, it is exactly this class of what he calls 'sellout niggers' which he hates, the black bourgeoisie whose 'definition of integration is to have their kids the only niggers in a white private

Freeman tells an Afro-American who wants integration: 'There's no changing this system, not in our lifetime and maybe never and the only way to make it is get in the best spot you can find. I don't want to change this system, just get it off my back. I'm no fucking integrationist. Integrate into what? Whitey's welcome to his chromeplated shit pile. I dig being black and the only thing I don't dig about being black is white folks messing with me.' This is why he, with a reference to Baldwin's book, wants 'Not the fire next time, ... but the fire right now,' and why he wants war, as he calls it, rather than 'more of whitey's con man's integration games, freedom on the installment plan, interest collected daily.' And this is also why he is willing to pay the dues, as he says, so that he can have 'Freedom now! No more begging, pleading and silent suffering.' ${ }^{27}$

Is this book then intended as a primer and an incentive for civil war? Probably not. Greenlee does not seem to foresee a black 
'victory' in the war started by Freeman. While Freeman is taking action to get whitey off his back, his aim seems to be the rather vague one of getting 'in the best spot you can find.' The author himself is reported to have made this comment: 'The book is about white faces and black masks, and is a warning that African masks have historically and traditionally served the dual function of entertaining and threatening the enemy.'28

Richard Wright has been a pivotal figure in Afro-American fiction. Even though some of his successors opposed him for some time on certain points, there is probably no present black writer who has not been influenced by him. By 1965 or so he had been thoroughly embraced, not only by black writers, but also by the reading public. Thus we find that the sale of Wright's books quadrupled between 1967 and 1968, that is, as the Black Power movement was really getting underway. Many black writers largely agree with Wright that violence in a sense is creative, that violent assertion is necessary for the black man to achieve a feeling of human dignity. ${ }^{29}$

As we know, this new emphasis on honesty and on violence went hand in hand with the change in the black man's image of himself. While we find a certain belief in the Afro-American's future or pride in his heritage in, for instance, Blake or Cane, most AfroAmerican novels written before 1965 show the black man as hating his blackness. Wright's Bigger Thomas and Baldwin's Rufus Scott (in Another Country) are just two examples. But as the emerging states of Africa showed the potential power of the black race, the American blacks were in a manner presented with a new selfimage, and it was easier for them to accept themselves and their heritage. As Hughes had predicted many decades earlier, the catchword now became 'black is beautiful.' The 'Afro' hairstyles and the African clothes are of course used to underline this pride, and many nationalist blacks frown upon those who mix with whites. Whereas pre-1965 black American fiction is typified by a writer like Hughes with Simple's discrete snides at the whites and at his woman's middle-class aspirations, what has appeared since can better be represented by the books by Williams and Greenlee with their open defiance of the whites and more militant self-assertion.

We might say that such books were bound to appear. They remind us of such questions as: What should the black author write about? For whom should he write? Should he establish a particular black value system? Should he aim at art or propaganda? 
Richard Wright declared that Afro-American literature should always carry a sense of the oppression of blacks. Ellison stated that he was not primarily concerned with injustice, but with art (quickly adding that he recognized no dichotomy between art and protest), and that he wanted freedom to explore the full range of the black man's humanity, including for example, not only his hatred but also his love. ${ }^{30}$

Baldwin the fiction-writer carried this point further by suggesting that the solution to the black man's problems must be sought not through violence and nationalism, but through love; thus we find in much of his writing an emphasis on interracial sex. Others, like LeRoi Jones, warn against such contacts between the races. Jones, who has written some fiction but who is better known as a dramatist, poet, and essayist, has in Dutchman given a harsh picture of a white woman who leads black males on only to murder them, and in a recent book he praises the black females: 'I love you black perfect woman. Your spirit will rule the twenty first century. This is why we ourselves speed to grace.' 31

LeRoi Jones is one of the leading proponents of a 'black aesthetic.' This is a hard-to-define term which suggests how black art, and especially black literature, should serve the Afro-Americans. 'Black literature,' Jones said recently, 'must function to bring us to an awareness that we are who we are - that is a weak, powerless, enslaved people-or it must give us the energy or the spirit to do something about our situation.' And he added: 'Black writers need to be active and involved - in the political world of trying to bring about black self-determination if they are to produce art that functions for black people.' ${ }^{32}$ Jones, who now calls himself Imamu Amiri Baraka, lives as he teaches. In recent years he has made the shift which so many American writers did between the 1920s and the 1930s, the shift from 'I' to 'we,' from a stress on the individual to an emphasis on the group. Thus he is actively engaged in building up the black community in Newark, his home city, and at the National Black Political Convention in March, 1972, the former iconoclast worked effectively as a mediator between the warring factions represented there.

Baraka tries to make also his art 'functional,' as he calls it. His recent book In Our Terribleness (in black English, in which often the meaning of 'white' words have been inverted, terrible means 'superb'), was 'definitely from black to black,' Baraka says, 'and was meant to express, define and clarify us to ourselves. It was a 
kind of revelation of identity and an investigation of the style of blackness.' ${ }^{33}$ The above quotation about the black woman is from this book, and it is symptomatic of certain aspects of the black aesthetic - the separatism and the pride in everything black. We might perhaps say that black literature no longer is so much one of protest as one of celebration: Now perhaps addressed more to blacks than to whites, it is intended to build a forceful image of the black man and woman so as to increase their racial consciousness and their self-confidence.

The prominent Afro-American critic Addison Gayle, Jr., has given expression to another aspect of the black aesthetic. Unlike, lor example, John A. Williams, he and many others refuse to accept anything the white fiction-writer might have to say about blacks because, in their view, they simply cannot 'do full justice to the humanity of the black race.' ${ }^{34}$ And a third leading exponent of the black aesthetic, Larry Neal, has tried to define it in these words: 'It is radically opposed to any concept of the artist that alienates him from his community. Black art is the aesthetic and spiritual sister of the Black Power concept. As such it envisions an art that speaks directly to the needs and aspirations of Black America. In order to perform this task, the Black Arts Movement proposes a radical reordering of the western cultural aesthetic. It proposes a separate symbolism, mythology, and iconology. ... The two movements postulate that there are in fact and in spirit two Americas - one black, one white.'35

Not a few Afro-Americans disagree with this, and some of them feel that it is nonsense to speak about a black aesthetic so long as it has not been more clearly defined. ${ }^{36}$ And there are not many black writers, outside of Toomer with his impressionistic Cane and Ishmael Reed with his surrealistic books, who have broken with the traditions of the realistic novel which dominates the literature of our century. At the same time, most American black writers now agree that they possess a valuable store of very particular material, in the form of the Afro-American's special experience, his folklore, his attitudes, and his language.

The key words here are 'blues' and 'soul.' 'The attraction of the blues,' Ellison has said, 'lies in that they at once express both the agony of life and the possibility of conquering it through toughness.' This is not very far from 'soul' as it has recently been defined: 'It is something inside of you that keeps you going even though you know you are being mistreated.' '[It is] warmth and love.' 'It is 
being able to feel things that others do not through music and dance.' 'Soul is the colored person.'37

The strong appeal which soul music has had for some time also for whites is of course well known. Another aspect of the black culture which is only now being recognized by non-blacks is the Afro-American language. With J. L. Dillard's Black English: Its History and Usage in the United States (New York, 1972), linguists in general must concede that black English is not a poor, imprecise imitation of what the whites are speaking, but a worthy language with a particular history and grammar and with a rich store of precise shades of meaning that have hitherto largely escaped nonblacks. In short, the particular Afro-American culture is quickly being granted its rightful position.

As a result of the black self-assertion which was started with Richard Wright and taken up again with such force in the 1960s, it seems as if at least some of the very young black writers of today have a little easier start than their predecessors. To be sure, the fight for improvement of the Afro-American's situation has only begun; yet at the same time, there is no denying that thanks to the efforts and the sufferings of Wright, Baldwin, LeRoi Jones, Martin Luther King, Malcolm X, Eldridge Cleaver, and many others of their generations, there are certain improvements in the black man's position and his self-acceptance which many of their successors may take for granted. It is not impossible that there will be a relative increase of the number of young black writers who will turn from the corporate black 'we' to the individual 'I.' George Cain and James Alan McPherson, two very talented young AfroAmerican authors, illustrate this point.

George Cain's only book so far is Blueschild Baby (New York, 1970), and in view of its descriptions of the drug scene and the Newark riots it is surprising that it has not been brought out also in paperback. The autobiographical protagonist - called George Cain-is a young Afro-American who becomes a symbol to his parents (who move from Harlem to middle-class Newark) and his many black friends: As a basketball star he makes it to a good school and seems to have a future ahead of him. In the white community there are many girls ready for him, but also drugs, and he ends up in jail. On his release he tries to get away from his white mistress and from drugs, and finally a black girl, Nandy, is able to help him.

Addison Gayle Jr. wants to see Blueschild Baby as one of the first 
modern novels to follow the lead of Delany's Blake in exemplifying a black aesthetic. The book is certainly directed to the AfroAmerican reader: Gayle rightly observes that it is 'written in language that is an integral part of the black community,' and it clearly communicates the black man's hatred of the oppressive whites-Gain even comes to the conclusion that the whites deliberately encourage drug addiction among the blacks so as to keep them down. When Gayle goes on to claim that the book is 'the most important work of fiction by an Afro-American since Native Son' his reason is the following: 'For those attuned to the Black Aesthetic, in casting well deserved censure upon the theology of the integrationists and in opting for black unity instead of black and white togetherness, the novel represents a major breakthrough.'38

In his championing of a black aesthetic Gayle overlooks what is certainly one of Cain's key observations:

I hate when they talk of my past as if I were a failure, I'm still alive and that is more important than any success, there is more than one way of dying and I was dying horribly. There was no me, only bits and pieces of everything and everybody, bound and tied to a whole race of people, black people, obligated to die and suffer making it for them. They don't see my addiction in its proper perspective. My need to live life unhindered, with no ties. The only way was to be rejected by those who respected and loved me, then I could begin anew. The process is nearly complete. Someday soon, I shall emerge as Georgie Cain. ${ }^{39}$

Cain thus concludes that solidarity with his fellow blacks cannot help him and that through its demands on him, his group is only weighing him down. True, he is helped by Nandy, but he realizes that ultimately you are alone, that nobody can help you free your soul, and the author and protagonist thus take us back to an emphasis on the single person.

We find this stress on the individual rather than the black group also in James Alan McPherson. 'I don't want to desert the black experience,' he has said. 'It's richer than any other in this country. But I don't think one should spend all his time writing propaganda. I deal with people - black and white--just people. ${ }^{20}$ It is symptomatic that one of the stories collected into his only book so far-Hue and Cry (1969; Fawcett Crest 1970) -is entitled 'All the Lonely People.' McPherson sees his characters as individuals, not as representatives of a race, and in this outstanding and very moving book he manages to give us the shocks of recognition 
we get when we occasionally feel we are dealing with what is true and universal.

When we look at the whole field of Afro-American fiction in the United States today we find a tremendous overall vitality in it, as we do in black poetry and black drama. This is of course a natural result of the consciousness-raising that has taken place among the more than 20 million American blacks. Equally unsurprising there is also a great variety in black literature. We find that authors cover the whole specter from nationalism to integrationism and from militancy and hatred to more peaceful attitudes, just as we find that some writers address themselves to blacks only and others to the general reading public. Afro-American fiction is indeed very much alive. It has gone a long way since its beginnings some hundred years ago, and it would be surprising if the 1970's should not produce a few truly great black novels in America.

One recent novel which may well deserve to be called great is Ernest J. Gaines' Miss Jane Pittman (1971; Bantam, 1972). We remember Faulkner's dedication in Go Down Moses to the Dilseylike 'Mammy, Caroline Barr, Mississippi (1840-1940) Who was born in slavery and who gave to my family a fidelity without stint or calculation of recompence and to my childhood an immeasurable devotion and love.' Gaines' similar dedication in Miss Jane Pittman to the woman who raised him has the added dimension of blood- and race-relationship: 'to the memory of $\mathrm{My}$ beloved aunt, Miss Augustus Jefferson, who did not walk a day in her life but who taught me the importance of standing.' Growing up on a Louisiana plantation, Gaines could not help seeing most of the things whites were doing to keep the blacks down, and it would appear that it was the courage and the fortitude of his aunt which enabled him to face life with the kind of detachment which we find in his books.

Like Gaines' previous books (two novels: Catherine Carmier, 1964, and $\mathscr{C}$ Love and Dust, 1967, and a collection of stories: Bloodline, 1968), Miss Jane Pittman is set in Louisiana. Purporting to be the autobiography of the 112-years-old former slave Jane Pittman, it covers, probably like no other novel before it, all the major events in the history of the black Southerners from 1863 till today: the Civil War, Emancipation, Reconstruction and its aftermath, and the events of our century. The first thing Jane Pittman remembers is that a Northern corporal renamed her Jane (after his own daughter in Ohio) so as to free her from her 'slave name,' as he 
calls it. Later she sets out for Ohio to seek his protection, but ends up on a Louisiana plantation, and in this state she spends the rest of her life.

Here we meet the blacks who work the land and the whites who own it. We learn about the degradations the Afro-Americans are exposed to, but we also see how they have the strength to remain standing. 'Black men have been proud before two years ago,' Gaines said in 1969. 'Some of the blacks I knew as a child were proud as they could be-poor as hell, but they were proud people. They were proud of being persons, of surviving, being able to get something out of the land.' 41

Miss Jane has a quiet dignity, a belief in her fellow blacks, and a dogged will to live on. She becomes a symbol to her people, and she serves as in inspiration for Ned, a young Afro-American who is killed around 1900 when fighting for black civil rights, and for Jimmy, another young man who dies for the same cause some 60 years later. But Gaines' message is not strictly political, he has said: 'I want to get down all that black people do, plus the violent, militant thing. Blacks do as much as anyone else, and more than most. They love cooking, eating, dancing, singing. And of course we fight and we make love. This is universal in people. ${ }^{42}$

Gaines combines the black protest of a Delany and a Richard Wright with the detachment and the universality of the Greeks and the great Russian writers. Though Jane Pittman's autobiography keeps black suffering very much before our eyes, Gaines has elevated her, as a critic has said, to the level of myth and made her into a legendary figure who deserves to stand beside Faulkner's Dilsey. Gaines' choice of such an old person largely contributes to this feat. She is able to see the present in the light of the past. Equally important is the unity of tone achieved by the single voice. But the author's success would have been impossible without the quality he shares with McPherson, the emphasis on common humanity. ${ }^{43}$

Jane Pittman is a rock which withstands all onslaughts, a symbol of the race which will not die, but at the same time her eyes are open to the faults of her own people as well as the good sides of the whites-her affection and understanding are applied to all. Though Gaines has managed to give us very much of the AfroAmerican experience, of the black heritage, he at the same time makes Jane Pittman stand for life itself, for the good and the bad. In this rich and warm and sometimes humorous novel, which combines something of the best of Toomer, Wright, Baldwin, and 
Ellison, Gaines has confirmed the obvious - that outstanding fiction writers will turn up among the American blacks, and that while their writings may be particularly relevant to the Afro-Americans, they at the same time say something important about the life of all of us, about the general human condition. It is easy to agree with those who say that Gaines is one of the best writers in the USA today and that he is so good that he makes the category of 'AfroAmerican fiction' seem meaningless. ${ }^{44}$

\section{$N O T E S$}

1 Part of this survey dates from some years back when I began to lecture on black writing, but most of it is a result of $m y$ work in connection with a graduate seminar I conducted at the University of Oslo, Fall 1971. I would like to thank my students for stimulating discussions.

2 The Massachusetts Review, 6 (Autumn-Winter 1964-65), 58.

3 As quoted by Redding, ibid., 57.

4 'Dilemma of the negro novelist in the United States,' in John A. Williams., ed., Beyond the Angry Black (1966; rpt. New York, 1971), p. 75.

5 See Sterling Brown, The Negro in American Fiction (Washington, D.C., 1937), and 'A Century of Negro Portraiture in American Literature,' The Massachusetts Review, 7 (Winter 1966).

6 A Fool's Errand (1879; rpt. Cambridge, Mass., 1961), p. 192.

7 Introduction ( $p .5)$ to Seymor L. Gross \& John Edward Hardy, eds., Images of the Negro in American Literature (Chicago, 1966).

8 The Souls of Black Folk, Ch. 1.

9 The Negro Novel in America (New Haven, 1965), p. 32.

10 Floyd J. Miller was responsible for this edition of Blake or the Huts of America (Boston, 1970).

11 Blake, pp. 195, 271, 292.

12 Jean Toomer, Cane. Introduction by Arna Bontemps (New York, 1969). For a brief Toomer bibliography, see Louis D. Rubin, Jr., ed., A Biblioopa-. phical Guide to the Study of Southern Literature (Baton Rouge, 1969), pp. 311-312. Some recent articles on Cane are found in, e.g., CLA Journal, 13 (September 1969), and 14 (March 1971); Studier in the Novel, 2 (Fall 1970); and Southern Humanities Review, 6 (Winter 1972). See also Frank Durham, ed., Jean Toomer. Cane (Columbus, Ohio, [1971]).

13 Ibid., p. 214.

14 Native Son (Signet, New York, 1950), pp. 391-392. A recent book on this novel is Richard Ahcarian, ed., Richard Wright's Native Son. A Critical Handbook (Belmont, California, 1970).

15 Irving Howe, 'Black Boys and Native Sons,' A World More Attractive (New York, 1963), p. 101.

16 Ellison's essays of the time are found in his Shadow and Act (1964, Signet 1966), and Baldwin's in Notes of a Native Son (1956, Corgi 1965) and Nobody Knows My Name (1961, Corgi 1965). The quotation is from Notes of a Native Son, p. 17.

17 'That Same Pain, That Same Pleasure,' in Shadow and Act. 
18 Two recent books on Invisible Man are: John M. Reilly, ed., Twentieth Century Interpretations of Invisible Man (Englewood Cliffs, N. J., 1970), and Ronald Gottesman, ed., Studies in Invisible Man (Colombus, Ohio, 1971).

19 Time, April 6, 1970, p. 33.

20 Figaro Littéraire, August 11-17, 1969, p. 28.

21 New York Review of Books, January 7, 1971, p. 16. L'Express, August 21-27, 1972, p. 64.

22 The Best of Simple (New York, 1961), pp. viii, 22-23, 24-25. O n Hughes, see James A. Emanuel, Langston Hughes (NewYork, 1967), and Therman B, O'Daniel, ed., Langston Hughes = Black Genius. A Critical Evaluation (New York, 1971).

23 The Man Who Cried I Am (Signet, 1968), p. 228.

24 New York Times Book Review, October 29, 1969, p. 66.

25 Charles D. Peavy, 'Four Black Revolutionary Novels, 1899 1970,' Journal of Black Studies, 1 (December 1970), 222.

26 The Spook Who Sat by the Door (Bantam, 1970), pp. 189, 56.

27 The Spook Who Sat by the Door, pp. 243, 246-247.

28 Newsweek, June 16, 1969, p. 60.

29 For a discussion of this point, see Stephen B. Bennett and William W. Nichols, 'Violence in Afro-American Fiction: A n Hypothesis,' Modern Fiction Studies, 17 (1971), 221-228.

30 Ellison, Shadow and Act (Signet), p. 170.

31 In Our Terribleness (Indianapolis \& New York, 1970), n.p.

32 New York Times Book Review, June 27, 1971, p. 26.

33 New York Times Book Review, June 27, 1971, p. 24.

34 New York Times Book Review, March 12, 1972, p. 20.

35 'Black Arts Movemen,' Black Theatre, 41 (Summer 1966), 30, as quoted in Nick Aaron Ford, 'Black Literature and the Problem of Evaluation,' College English, 32 (Februay 1971), 539.

36 See e.g. the black historian Martin Kilson's reply to Gayle in New York Times Book Review, April 9, 1972, p. 30.

37 Ellison, Shadow and Act (Signet), p. 35; Newsweek, June 30, 1969, p. 22.

38 New York Times Book Review, January 17, 1971, pp. 4, 34.

39 Blueschild Baby, p. 7

40 Newsweek, June 16, 1969, p. 58.

41 Newsweek, June 16, 1969, p. 60.

42 Ibid.

43 Newsweek, May 3, 1971, p. 58.

44 Newsweek, June 16, 1969, p. 58; Time, as quoted on the cover of Miss Jane Pittman. - In addition to the books mentioned above, some furthervolumes (all in paperback) of the many available can be recommended for those who want to start a study of black American writing: Darwin T. Turner, AfroAmerican Writers (NewYork, 1970; a bibliography); LeRoi Jones and Larry Neal, eds., Black Fire: An Antology of Afro-American Writing (NewYork, 1968); James A. Emanuel and Theodore L. Gross, eds., Dark Symphony (NewYork, 1968; an anthology of fiction, poetry, and essays); Addison Gayle, Jr., ed., The Black Aesthetic (Garden City, N.Y., 1972; a collection of essays); C.W.E. Bigsby, ed., The Black Writer (Baltimore, Md., 1971; essays on: Vol. I: fiction; Vol. II : poetry and drama). 